Available online at : http://journal.unj.ac.id/unj/index.php/gjik

Gladi : Jurnal Ilmu Keolahragaan 12 (01) 2021, 55-61

Permalink/DOI: https://doi.org/10.21009/GJIK.121.08

\title{
EVALUATION OF LEARNING PHYSICAL EDUCATION IN THE COVID-19 PANDEMIC
}

\author{
Ade Argi ${ }^{1}$, Ramdan Pelana ${ }^{1}$, Yasep Setiakarnawijaya ${ }^{1}$ \\ ${ }^{1}$ Pendidikan Olahraga, Pascasarjana Universitas Negeri Jakarta, \\ Universitas Negeri Jakarta Complex Jl. Rawamangun Muka, East Jakarta, Indonesia13220 \\ Corresponding aouthor. Email: de.argi17@gmail.com
}

\begin{abstract}
The purpose of this study was to determine the level of effectiveness of physical education virtual learning during the COVID-19 pandemic first grade students of 6 junior high school Bogor. The research method used is to use a descriptive qualitative research method, namely a survey using Google form media which is carried out in each house. The population in this study were students of 6 junior high school Bogor mounting to 306 students and using a sample of 34 students in the same class. This study used an instrument in the form of a questionnaire with variables. This research includes three aspects of affective, cognitive and psychomotor. Affective here uses a research instrument in the form of a questionnaire to obtain research data with a total of 18 questions with answer options Strongly, Agree, Disagree, Strongly Disagree Based on the results of research analysis and discussion, it can be concluded that the level of physical education learning during the COVID-19 pandemic can be broken down as follows the affective category average is 33.56 , the cognitive average is 89.56 and the psychomotor is 78.67 . From the three data, it was found that the average level of learning effectiveness was 67.27 with the category less
\end{abstract}

Keywords: Effectiveness of learning, Learning Problems, Pandemic COVID-19 
Gladi Jurnal Ilmu Keolahragaan, 12 (01), March- 56

Ade Argi, Ramdan Pelana, Yasep Setiakarnawijaya

\section{INTRODUCTION}

COVID-19 is an infectious disease caused by a newly discovered type of coronavirus. Although it mostly affects the elderly, this virus can actually affect anyone, from babies to children to adults. This corona virus can cause minor disorders of the respiratory system, severe lung infections, and death. COVID-19 was first discovered in the city of Wuhan, China at the end of December 2019. This virus is contagious and has spread to almost all countries, including Indonesia, in just a few months. So the WHO on March 11, 2020, declared this outbreak a global pandemic (Kompas.com:2020). This has led several countries to establish policies to impose lockdowns in order to prevent the spread of the corona virus. In Indonesia itself, a large-scale social restriction policy was implemented to suppress the spread of this virus. Because Indonesia is carrying out the PSBB, all activities carried out outside the home must be stopped until this pandemic has subsided.

Some local governments have decided to implement a policy of dismissing students and have started implementing online or online learning methods. This government policy came into effect in several provinces in Indonesia on Monday, March 16, 2020, which was also followed by other provinces. But this does not apply to several schools in each region. These schools are not ready for online learning systems, which require learning media such as cellphones, laptops, or computers.

The online learning system (in a network) is a learning system without faceto-face learning between teachers and students but is carried out online using the internet network. Teachers must ensure teaching and learning activities continue, even though students are at home. The solution, teachers are required to be able to design instructional media as an innovation with virtual learning.

The learning system is implemented through a personal computer or laptop connected to an internet network connection. Teachers can learn together at the same time using groups on social media such as WhatsApp, telegram, Instagram, zoom applications or other media as learning media. Thus, the teacher can ensure students take part in learning at the same time, even in different places. It should be realized that the unpreparedness of teachers and students 
towards online learning is also a problem. The transfer of conventional learning systems to online systems was very sudden, without proper preparation. But all of this must be carried out so that the learning process can run smoothly and students actively follow even in the conditions of the Covid-19 pandemic.

Sports and health physical education subjects are very important subjects for students to learn today, because with knowledge of health and sports practices students can fortify themselves, one of which is by increasing immunity to prevent the corona virus. Regular exercise is one way to maintain health.

However, the learning pattern at home certainly has its own challenges, especially for teachers of physical education subjects, Learning that is carried out from home, of course, must be able to improve student fitness, motor skills and values that include cognitive, affective, and social aspects, so that the subject matter must be carefully rearranged so that the physical education learning experience is obtained by students, however discussed with the ability to carry out student learning at home. The results of observations by researchers in the field, common obstacles faced in implementing this distance learning, include;

1. Not all students have electronic teaching media facilities (computers, laptops, cellphones).

2. Not all students are able to access the internet (do not have data packages)

3. It cannot be denied that there are also Physical Education teachers who are not able to properly utilize electronic teaching media in the form of hardware and software or are clueless,

4. The background of junior high school teachers whose education is not linear for teaching sports and health physical education but suddenly becomes a sports and health physical education teacher is an obstacle, because some of them do not understand sports and health physical education, even consider learning sports and health physical education is a subject that is not considered important.

5. Limited internet access in each region.

6. So far physical education teachers are also confused about choosing and utilizing technology or online learning platforms that can fulfill sports and health physical education teaching.

Sports physical education teachers in the current pandemic cannot adapt quickly in 
following up on this problem, so student academic achievement will certainly be disrupted even the impact on the aspect of lack of movement will overshadow students during online learning.

\section{METHODS}

The survey research method is also equipped with a test technique in the form of questions to measure student responses during online learning in physical education subjects first grade students at 6 junior high school, Bogor City. Researchers did not observe and provide treatment, they only distributed questionnaires via online.

In this study, only one instrument was used, namely in the form of questions and questionnaires prepared by the researcher. These questions and questionnaires were compiled based on the indicators contained in the attractiveness variable of physical education online learning for students during the COVID-19 pandemic. in physical education subjects first grade students at 6 junior high school, Bogor City. Each question item in the research questionnaire is equipped with alternative answers based on the Likert scale. The variables in this study will be translated into variable indicators, then these indicators are used as a starting point for compiling instrument items in the form of statements. The answer to each item of the Likert Scale The population in this study were students of 6 junior high school Bogor mounting to 306 students and using a sample of 34 students in the same class. Data were analyzed using descriptive statistics with computerized assistance.

\section{RESULT AND DISCUSSION}

This research includes three aspects of affective, cognitive and psychomotor. Affective here uses a research instrument in the form of a questionnaire to obtain research data with a total of 18 questions with answer options Strongly Agree, Agree, Disagree, Strongly Disagree, Each item of the question is given a score of 1-4. While the Cognitive assessment was taken from the student's PTS score / I and the psychomotor aspect was taken from the evaluation of the learning video. The construct in this research is the level of physical education learning during the COVID-19 pandemic.

The data is tabulated, scored and analyzed and categorized according to the formula as very good, good, lacking, and very poor.

Based on the results of the study, it shows that the level of physical education learning during the COVID-19 pandemic was in the low category, where the average score was in 
Gladi Jurnal Ilmu Keolahragaan, 12 (01), March- 59

Ade Argi, Ramdan Pelana, Yasep Setiakarnawijaya

the 67.27 category. The results of this level of learning are caused by various things, especially the difficulty of students understanding online learning material which makes students feel bored, especially in physical education lessons. In line with the opinion of Ali Sadikin and Afreni Hamidah (2020) that students assume that the material and assignments are not enough because they need direct explanation by the teacher / lecturer (Sadikin \& Hamidah, 2020).

Of the three aspects measured by researchers in the cognitive domain, which is different, which has the highest average value among others, namely 89.59 . These results indicate that the cognitive aspect is the highest among the others, this is because online learning also has the advantage of being able to foster selfregulated learning. The use of online applications can improve learning independence (Oknisih, N., \& Suyoto, S., 2019).

\section{CONCLUSION}

Based on the results of research analysis and discussion, it can be concluded that the level of physical education learning during the COVID-19 pandemic can be broken down as follows the average affective category is 33.56, the cognitive average is 89.56 and the psychomotor is 78.67. From the three data, it was found that the average level of learning effectiveness was 67.27.

So it can be concluded that the level of physical education learning during the COVID-19 pandemic was categorized as insufficient, where the average score was in the 67.27 category.

\section{REFERENCES}

Abduljabar, B., \& Yudiana. (210 C.E.). Pendidikan Intelektual dan Pendidikan Jasmani. RizqiPress.

B.Milman, N. (2015). Distance Education. International Encyclopedia of the Social \& Behavioral Sciences: Second Edition.

https://doi.org/doi.org/10.1016/B978-

0-08- 097086-8.92001-4

Badar, I. T. (2009). Mendesain Model Pembelajaran Inovatif Progresif dan Kontekstual. Kencana.

Delima, M. I., Fitriasih, R. D., \& Nugroho, R. T. (2017). Konsep Evaluasi Pembelajaran.

Dwiyogo, W. D. (2010). Dimensi Teknologi

Pembelajaran Pendidikan Jasmani dan Olahraga. wineka Media.

Firman, F., \& Rahayu, S. (2020). Pembelajaran Online di Tengah Pandemi Covid-19. Indonesian Journal of Educational Science (IJES), 
Gladi Jurnal Ilmu Keolahragaan, 12 (01), March- 60

Ade Argi, Ramdan Pelana, Yasep Setiakarnawijaya

2(2), 81-89.

https://doi.org/10.31605/ijes.v2i2.659

Hanafy, M. S. (2014). Konsep Belajar Dan

Pembelajaran. Lentera Pendidikan:

Jurnal Ilmu Tarbiyah Dan Keguruan, 17(1), 66-79.

https://doi.org/10.24252/lp.2014v17n1

a5

Hera Yuniartik, T. H. \&, \& Nasuka. (2017).

Evaluasi Pembelajaran Pendidikan

Jasmani Olahraga dan Kesehatan di

SLB C Se-Kota Yogyakarta. Journal of

Physical Education and Sports, 6(2), 148-156.

https://journal.unnes.ac.id/sju/index.ph

p/jpes/article/view/17389

Irwanto. (2019). Evaluasi Proses Belajar Dan Pembelajaran Dengan Model Cipp Untuk Mata Pelajaran Penjasorkes Di Sekolah Menengah Kejuruan Negeri 2 Kota Serang. Jurnal Kejaora (Kesehatan Jasmani Dan Olahraga), 4(2), 6-13. https://doi.org/10.36526/kejaora.v4i2. 656

Jamaris, M. (2010). Orientasi Baru dalam Psikologi Pendidikan. Yayasan Penamas Murni.

Jayul, A., \& Irwanto, E. (2020). Model Pembelajaran Daring Sebagai
Alternatif Proses Kegiatan Belajar Pendidikan Jasmani di Tengah Pandemi Covid-19. Urnal Pendidikan Kesehatan Rekreasi, 6(2), 190-199.

Khafid, M. (2008). Faktor Yang Mempengaruhi Ketuntasan Belajar Akuntansi : Motivasi Belajar Sebagai Variabel Intervening. Lembaran Ilmu Kependidikan, 37(1).

Majid, A. (2013). Strategi Pembelajaran. Remaja Rosdakarya.

Makmun, A. S. (2003). Psikologi Pendidikan. Rosda Karya Remaja.

Pambudi, M. I., Winarno, M., \& Dwiyogo, W. D. (2019). Perencanaan dan Pelaksanaan Pembelajaran Pendidikan Jasmani Olahraga Kesehatan. Jurnal Pendidikan Olahraga, Universitas Negeri Malang, 4(1), 110-116. http://journal.um.ac.id/index.php/jptpp I

Pane, A., \& Darwis Dasopang, M. (2017). Belajar Dan Pembelajaran. FITRAH:Jurnal Kajian Ilmu-Ilmu Keislaman, 333 . $3(2)$, https://doi.org/10.24952/fitrah.v3i2.94 5

Paramitha, S. T. (2008). Pengembangan Permainan Bola Basket untuk Proses Pembelajaran Pendidikan Jasmani, 
Gladi Jurnal Ilmu Keolahragaan, 12 (01), March- 61

Ade Argi, Ramdan Pelana, Yasep Setiakarnawijaya

Olahraga dan Kesehatan Siswa

Sekolah Dasar. Universitas Negeri Semarang.

Prilanji, F.B., Simanjutak, V.G., Haetami, M. (2019). Evaluasi Pembelajaran Penjasorkes. Jurnal Pendidikan Dan Pembelajaran Khatulistiwa, Vol. 8 No.

Putro, E. (2016). Hasil Pembelajaran Di Sekolah. Pustaka Belajar.

Rahayu, E. T. (2013). Strategi pembelajaran pendidikan jasmani. Alfabeta.

Raibowo, S., \& Nopiyanto, Y. E. (2020). Jurnal Pendidikan Kesehatan Rekreasi Evaluasi Pembelajaran Pendidikan Jasmani Olahraga \& Kesehatan pada SMP Negeri Se-Kabupaten Mukomuko melalui Pendekatan Model Context, Input, Process \& Product ( CIPP ) PENDAHULUAN Program pemerataan pendidikan telah. Jurnal Pendidikan Kesehatan Rekreasi, 6(2), 146-165.

https://doi.org/10.5281/zenodo.388189 1

Samsudin. (2010). Perencanaan Pembelajaran Pendidikan Jasmani dan
Olahraga. wineka Media.

Sugiyanto. (2007). Perkembangan dan Belajar Motorik. Mendikbud.

Sunarto, \& Hartanto, A. (2006). Perkembangan Peserta Didik. Rineka Cipta.

Syah, M. (2003). Psikologi Belajar. Raja Grafindo Persada.

Taufik, M., \& Pardijono. (2013). Efektivitas Pembelajaran Pendidikan Jasmani Di Sma Negeri Surabaya Tentang Pemanfaatan Sarana Dan Prasarana Dalam Kegiatan Ekstrakurikuler Tahun Pelajaran 2012/2013. Jurnal Pendidikan Olahraga Dan Kesehatan, 01(2), 392-399.

https://doi.org/10.1017/CBO97811074 15324.004

https://doi.org/10.18860/jt.v2i2.1826

Yandwiputra, A. R. (2020). Kuliah Jarak Jauh karena Virus Corona, UI: Bukan Lockdown. Tempo.Co. 
